\title{
Vision In Action: The Impact of Sustainable Practices of Philippine School Doha on the Students' Move Towards Youth Environmentalism
}

\author{
Dr. Evelyn S. Mariñas ${ }^{a}$, Roma Angelica N. Manaois ${ }^{\mathrm{b}}$, Anne Beatrice A. Jose ${ }^{\mathrm{c}}$, \\ Ma. Angela Jayne M. Mandin ${ }^{\text {d }}$ \\ a evelyn.marinas@psdqatar.com
}

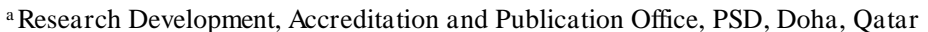

\begin{abstract}
With problems around oil and water supply and natural wildlife heritage, air, water, and land pollution have been significant factors in Qatar, in addition to smog and acid rain. In line with Qatar's National Vision 2030, Philippine School Doha (PSD) exhibits its allegiance to the cause and United Nations' Sustainable Development Goals. Aligned with these goals, PSD's vision targets 10 SDGs by implementing sustainable practices to inspire sustainable eco volunteerism. Instilled in the mission and philosophy, the Senior High School (SHS) department has been promoting the core value, pro-environment, by providing Academic Track and Specialization curricula and imbuing students with love for the environment. This study described the measurable impact of PSD's sustainable practices such as Elite Paper Recycling, No to Single-Use Plastic Advocacy, and C-Patrol and Doha Bank Eco-Schools on students' move towards youth environmentalism. A survey questionnaire was made and validated using quantitative descriptive research design and the Input-ProcessOutput approach. To know the SHS students' profile, awareness of, and compliance with the sustainable practices, Slovin's formula was used, including 190 respondents as the sample in this study conducted in S.Y. 2021-2022. This study also utilized the simple random sampling technique. Computed percentage, frequency, and weighted mean prove that SHS students initiate action regardless of awareness. $89 \%$ of SHS students are aware and often comply with sustainable practices. Hence, they demonstrated the readiness to participate and collaborate in a three-stage plan. The first stage is Encourage, where a committee was formed for a sustainability audit. A program and website were launched with desktop monitoring devices and eco codes for readiness and purpose. The second stage is Conduct and campaign, where implementation occurred through scratch paper, water bottle collections, checklists on sanitary, and resourceful practices per class (e.g., saving cartons), classroom waste segregation, cleanups, and ecological camps. The last stage is Obtain and optimize. Weekly awards, online progress reports, recognition (e.g., newsletters, including students' environmental products and studies embedded in the curriculum), and reevaluation (e.g., behavior modification) monitor objectives and set new goals. To aid in behavioral modification towards youth environmentalism, it consists of reinforcing existing habits and activities, raising awareness and action, and including innovations and eco-friendly technology. Such measures include minimizing wastes at large (e.g., Reduce, Reuse, Recycle, Repurpose), conservation of energy and water, and partnerships with initiatives (e.g., Al Meera). 96\% of senior high school students are aware of the sustainable practices in PSD after the three-stage plan. The senior high school students comply least with Elite Paper Recycling as the total mean is 2.70 with the verbal interpretation of 'Often. The senior high school students sometimes comply with the No to Single-Use Plastic Advocacy of the school as the total mean 3.08 with the verbal interpretation of 'Often.' The senior high school students comply best with C-Patrol and Doha Bank Eco-Schools. The students should have more initiative in sustainability practices with or without criteria and acknowledgments. Although results were satisfactory, the researchers and future researchers can increase the number of respondents in the study to gain better results. Furthermore, future researchers can use this research to assist them if their research problem involves environmentalism and sustainability topics to spread awareness further. Future researchers could also find more partnerships to push the school to its fullest potential as an eco-school. School administrators may utilize this information to help instructors from many departments teach students about the importance of environmentalism and sustainable measures that can be used to promote sustainable development and raise awareness. These indicated actions require PSD students, parents, teachers, and school administrators to achieve the sustainability goals and strengthen the eco-school reputation.
\end{abstract}

Keywords: Advocacy; Sustainable Practices; Eco-school; Environmentalism; Waste Management; Energy and Water

\section{Introduction}

\subsection{Background of the Study}

With problems around oil and water supply and natural wildlife heritage, air, water, and land pollution have been significant factors in Qatar, in addition to smog and acid rain (Mohammed, 2021). As the country strives to achieve the National Vision 2030, the youth of Philippine School Doha in Qatar find it necessary to take small steps to significantly impact the Qatar community, school values, and natural resources. Environmentalism is one of the main objectives of this study as actions of the people, specifically the youth, would help achieve intelligent energy and water consumption, conservation, cleanliness, and management for Qatar and its people. Teaching the ideology and concept of sustainability is an essential component of any modern-day classroom. Creating a sustainable educational environment should not be put off at the last moment. Undoubtedly, it should be at the top of the list of educational priorities. Sustainability activities and practices that 
get the youth thinking about the environment are advantageous to improving the awareness of the environment and its needs (Folk, 2021). The researchers aim to initiate a program focusing on water, energy, and waste management to summarize every sustainable practice that an eco-school is consistently practicing. Through the advocacy, the researchers could integrate the concept of environmentalism of students by measuring the impact of sustainable practices on the students' move towards environmentalism, including a project in one school that aims to be a local feature for national results.

\subsection{Statement of the Problem}

This study described the measurable impact of sustainable practices of Philippine School Doha on the students' move towards youth environmentalism. Specifically, this research aims to answer the following questions:

1. What is the demographic profile of the respondents in terms of:

$\begin{array}{ll}\text { 1.1. } & \text { age; } \\ \text { 1.2. } & \text { sex; and, } \\ \text { 1.3. } & \text { grade level? }\end{array}$

2. Before the three-stage-plan, how many respondents are aware of the following sustainable practices in PSD:

2.1. Elite Paper Recycling;

2.2. No to Single-Use Plastic Advocacy; and,

2.3. C-Patrol and Doha Bank Eco-Schools?

3. After the three-stage-plan, how many respondents are aware of the following sustainable practices in PSD:

3.1. Elite Paper Recycling;

3.2. No to Single-Use Plastic Advocacy; and,

3.3. C-Patrol and Doha Bank Eco-Schools?

4. Before the three-stage-plan, how many respondents comply with:

4.1. Elite Paper Recycling;

4.2. No to Single-Use Plastic Advocacy; and,

4.3. C-Patrol and Doha Bank Eco-Schools?

5. After the three-stage-plan, how many respondents comply with:

5.1. Elite Paper Recycling;

5.2. No to Single-Use Plastic Advocacy; and,

5.3. C-Patrol and Doha Bank Eco-Schools?

1.3 Hypothesis

H0: The sustainable practices of Philippine School Doha have no measurable impact on the students' move towards youth environmentalism.

1.4 Significance of the Study

The results, recommendations, and implications of this study may help different sectors along with significant contributions to the following:

\section{A. PSD Students}

This study and its data will benefit the students because it will help them become more aware of the different sustainable practices in PSD. Furthermore, along with the knowledge of the different practices, the students will grasp the importance of practicing sustainability, motivating them to protect our environment through small actions.

\section{B. PSD Parents}

This study will benefit the parents by informing them about the different sustainable practices their children are exercising. It will also help them encourage their children to participate in the existing sustainable practices.

\section{PSD Teachers}

This study will help the teachers educate, instill environmental sustainability, and reinforce it in the school's vision so that the students and their co-teachers make sustainable practices successful.

\section{PSD Administrators}


This study will benefit the administrators by educating the teachers in all departments to practice sustainable practices in PSD so that the students will be inspired to participate. Furthermore, the administrators can work together with the community. Hence, this study will help achieve one of the school's core values, which is to be pro-environment.

\section{E. Future Researchers}

This study will benefit future researchers interested in conducting studies similar or related to this topic, specifically the students' move towards youth environmentalism. This study can also serve as a guide and source for their study. The data gathered in this study can also serve as supporting evidence in their research.

\subsection{Related Literature and Studies}

Energy Conservation Energy conservation refers to decreasing energy consumption by generating or using less. It takes the form of utilizing fewer energy services or employing energy-efficient equipment. Minimizing the utilization of electricity-generated technology to save energy, it is also possible to adopt more energy-efficient items that consume less energy than their regular equivalents. Energy conservation is an essential component of long-term viability and development. There are three methods of energy conservation: turn down, turn off, and substitution efficiency. Energy conservation is critical for a variety of reasons. It not only reduces dependency on nonrenewable energy resources (such as fossil fuels), but it also helps save money on energy expenditures, such as electricity bills and other energy bills. Conserving energy also limits the expansion of development in regions where natural resource exploitation (such as oil or even lithium) influences natural areas. Finally, we immediately lower the quantity of greenhouse gas emissions entering the Earth's atmosphere when we save and use energy more effectively (Tara Energy, 2021).

Qatar's energy usage is among the highest globally, and the country's current population could easily double. Energy conservation is essential since energy resources are limited, and demand is rising at an alarming rate. The country relies on desalted saltwater, which uses energy and generates the least energy-efficient desalting technique. The desalination process is sensitive to a variety of variables. Therefore strategic water storage must be constructed. High energy use is wreaking havoc on the air and marine ecosystems. Several recommendations are made to conserve energy in Cogeneration Power Desalting Plants (CPDP), including replacing the Multi-Stage Flash (MSF) desalting system with the energy-efficient Seawater Reverse Osmosis System (SWRO). Furthermore, fully utilizing the installed power capacity to desalt water in winter, when the electric power load is low, and during summer non-peak hours for strategic water storage; and modifying simple Gas Turbines (GT) Power cycle plants to GT combi plants (to about 50 percent) (Darwish, 2013).

Researchers Gabbar et al. (2014) researched energy-saving techniques in Qatar, focusing on commercial buildings. Energy conservation techniques are categorized into five major categories, and a building Energy Conservation Matrix (ECM) database is created. The ECM assigns energy-saving techniques/technologies to models based on their application domain. Three scenarios (building envelope design, customer behavior modification, and consideration of renewable energy source) are studied to investigate various efficiency enhancement options. The analysis is carried out in a case hotel. According to the analysis, the energy conservation potential of employing envelope redesign for the case study is around 7.5 percent, whereas conservation through behavior change varies between 2.74 percent to 15.80 percent. In the combinatorial scenario, the conserved energy potential varies between $10 \%$ and $24.12 \%$ of the site energy, combining envelope design choices with customer behavior modification. The renewable energy (RE) scenario indirectly conserves energy by utilizing green energies derived from renewable sources. The output indicates that the overall $\mathrm{CO} 2$ emissions of the building are decreased as a result of the adjustments made in the three scenarios. According to the research, adopting a 30\% RE alternative can cut emissions by roughly $27 \%$ compared to the reference scenario. The scenarios created in this study and the findings gained are expected to inspire designers to consider alternate designs or redesigns in large-scale commercial structures. This research aims to find more resolutions to energy wastage.

Desalination is a water technology that is becoming more popular for meeting water needs. However, it is expensive and energy-intensive, and it puts an additional burden on the environment due to brine disposal and greenhouse gas (GHG) emissions. Xevgenos et al. (2014) reported that a substantial amount of energy is required to desalt saltwater, whether through the membrane or thermal methods. Desalination has negative consequences in fossil fuel depletion and GHG emissions from the power generation process used to provide this energy. Furthermore, the desalination process produces wastewater (brine), which harms the surrounding sea environment where the brine is released. Both difficulties must be satisfactorily overcome for desalination to be considered a long-term water option. The potential for integrating desalination with renewable energy is discussed in this study (RES-D). Specific desalination techniques can be paired with various renewable technologies. The 
RES-D combinations that have already been used are described in their technological development stage. The current state of brine management and a new solution based on zero liquid discharge (ZLD) are also discussed. SOL-BRINE (LIFE09 ENV/GR/000299) was the acronym for a European project that produced this experimental system.

Water Conservation With rising population rates and just a tiny fraction of all water on Earth appropriate for human use, it is only natural that humans must protect and conserve this valuable resource. Water conservation entails using a limited water supply wisely and adequately preserving it. As human beings, water is our source of survival. Therefore, we must learn more about water conservation and how to help in maintaining pure and secure supplies for future generations. This study aims to embolden the environmentalism concept to students' minds through simple sustainability practices such as water and energy conservation, recycling, and more (Evans, 2020).

Qatar is one of the world's most water-stressed countries. However, the continual growth of fossil fuel-led desalination technology and related water infrastructure avoided the shortages. It ensured that all citizens and residents had ongoing access to safe and clean water. In recent years, Qatar has seen an increase in household water usage, which has strained the economy, infrastructure, and the environment. New methods to reduce demand have been proposed, including raising water fees and reusing residential effluent for semi-productive use. However, these regulations have had little effect on residential water usage. Water conservation is one of Qatar's priority sectors for natural sustainability.

According to the survey conducted by Mohammed (2021), the water awareness study assessed the general public's understanding of Qatar's groundwater and freshwater resources. Only a tiny percentage of the Qatari population is aware of the country's water resources. According to the poll, just one-quarter (27\%) of the population is aware of the present status of groundwater aquifers in Qatar, while almost half (48\%) is uninformed. A sizable proportion of the population (61 percent) is unaware of Qatar's freshwater reserve capacity and storage. According to the poll, more than one-third (36\%) of the general public consumes most of their daily water through bathing (showering). Following that, 26 percent said toilet, and one in five (21 percent) said cleaning clothing and utensils, respectively. However, there is no discernible variation in ranking regarding gardening, drinking, and vehicle washing. Cooking $(7 \%)$ and housekeeping $(6 \%)$ are the activities that use the least amount of water. Water consumption varies somewhat according to socioeconomic category. Qataris use the most water in the garden compared to non-Qataris (29 percent vs. 15 percent), and it is more frequent among higher-income non-Qataris. In addition, as compared to non-Qataris, more than one-fourth $(28 \%)$ of the Qatari population identified car washing as a substantial water user (12 percent ). Water usage is driven by larger dwellings, wealth, and a luxurious lifestyle.

According to the poll, many individuals are already engaged in water-saving measures. Most of them are convenient, such as loading their washing machine and dishwasher altogether. Approximately half of the population (49 percent) believe it is likely (including highly likely) to build a greywater recycling system. Older generations are more inclined than younger generations to consider installing a greywater recycling system in their homes. There is a widespread belief that individuals are hesitant to utilize treated wastewater for agriculture, landscaping, or other non-consumptive use. A prominent source of concern is a health danger and religious and cultural grounds. Reusing treated wastewater, on the other hand, has widespread approval. A sizable majority of the population (61 percent) said they would consider utilizing treated wastewater (from the kitchen and washing machine) for toilet flushing. Fewer than $10 \%$ believe it is improbable or that they would not undertake it. Men and women generally hold similar viewpoints. Some $12 \%$ of Qatari males believe it is improbable, while $13 \%$ of Qatari women feel it is not something they would do. However, more than half of Qatari men and women agreed that utilizing well-treated wastewater from the kitchen and washing machines for toilet flushing was a good idea.

Some alternatives are better than others. Installing a water meter and alerting them of their monthly usage by mobile phone is the most favored alternative ( 80 percent probable), followed by information on water shortages and conservation choices (76 percent likely), and imposing a water use limit at no or little cost (76 percent likely) (73 percent). At the same time, responses to increased water tariffs and faith-based encouragement are mixed. Almost one-quarter of those polled believe that raising water rates will have little effect on water conservation. One-fifth of those polled claimed faith-based beliefs would not affect their decision to save water.

Conservation As the rate of global environmental change accelerates, conservationists emphasize educating children about environmental concerns. A comprehensive environmental education, according to educators, includes decision-making, critical thinking, and citizenship skills, as well as an awareness of human-nature interactions. According to the study conducted by Sutherland (2018), previous studies indicate that starting EE (Environmental Education) at an early age can help 
children acquire healthy environmental views. Furthermore, frequent exposure to conservation education can foster positive attitudes and better understand environmental challenges and solutions. More information on the efficacy of various classroom EE techniques is required to assist curriculum formulation and design. Researchers performed questionnaires to assess instructors' and students' perceptions on which age groups are most responsive to EE and what sorts of lessons are most successful. The researcher performed two surveys in Kansas, each within a different school district. The initial questionnaire was completed by 70 K-12 teachers from all school levels. The poll asked instructors about their favorite teaching techniques and their opinions on how responsive pupils of various grade levels are to environmental education. The second survey collected information from 350 students in grades 9-12 at a single high school in the same district. This technique ensured that many of the students had previously taken classes with the professors, allowing for meaningful comparisons of their replies. This survey sought students' perspectives on conservation education, including its relevance in schools and how it should be taught.

Students and instructors unanimously agreed that conservation and environmental education should be taught in schools and that the teachings should be repeated throughout their schooling. Teachers and classes were cited by more than half of students as having the most significant effect on their environmental attitudes. The findings support the notion that teaching about the environment in the classroom provides a promising chance to increase students' environmental knowledge and attitudes significantly. More than a third of instructors stated that high school pupils were the least responsive to the environmental education of any academic level. Instead, instructors largely agreed that teaching EE between the fourth and sixth grades would be the most beneficial. However, the findings contradicted the opinions of high school students, who stated that EE should be provided during their senior year. Most teachers and students believe participatory lessons are more successful than other teaching approaches such as lectures and assigned readings. Because the study only looked at one school district, the findings may not be applicable in other places.

Furthermore, the questionnaire examined self-reported interest in EE rather than a potentially more objective metric, such as engagement or test results. To support the findings of this poll, more studies might be conducted to look at other indicators of academic performance because students and instructors agreed that conservation education should span kids' K12 education. The researchers suggest that the school curriculum covers the environment at every grade level, including ageappropriate content and activities. They recommend that instructors employ participatory teaching to increase student participation with environmental issues, especially in high school. The discovery that most high school students were responsive to EE, despite instructors' perceptions, should give high school teachers more confidence in including environmental and conservation issues into their curriculum.

Waste Management Arab Youth Climate Movement Qatar (AYCMQA), an environmentalist group in Qatar, seeks to inspire young people in the country and even abroad to put ideas into action, such as the 'zero-waste lifestyle in Qatar,' to protect the environment. As a result, multiple initiatives and businesses were set as an action plan. One of these is the Elite Paper Recycling. Elite Paper Recycling has established itself as Qatar's only paper production company capable of recycling all sorts of waste paper. It has been in the recycling industry since 2014. Elite Paper Recycling established an eco-friendly environmental commercial enterprise that would be a source of environmental awareness and contribute to the nation's growing economy by providing locals gainful learning and employment opportunities and a quality services solution to the corrugated carton segment. This study aims to utilize such initiatives to foresee the awareness of the SHS Department of the Philippine School Doha regarding the school's sustainable practices (Elite Paper Recycling, 2019).

Examining global climate change models in conjunction with hydrological data on worsening water quality in the Middle East and North Africa (MENA), explaining how MENA (the Middle East and North Africa) nations are vulnerable to climate-induced impacts on water resources. Adaptive governance solutions, on the other hand, continue to be a low priority for MENA political leaders. To date, most MENA countries have focused their resources on large-scale supply-side initiatives such as desalination, dam construction, inter-basin water transfers, exploiting fossil groundwater aquifers, and importing virtual water. Because controlling water demand, increasing water efficiency, and encouraging conservation will be critical components in reacting to climate-induced impacts on the water sector, this paper examines the political, economic, and institutional variables that have impacted governance responses-examining global climate change models in conjunction with hydrological data on worsening water quality in the Middle East and North Africa (MENA), explaining how MENA nations are vulnerable to climate-induced impacts on water resources. Adaptive governance solutions, on the other hand, continue to be a low priority for MENA political leaders. To date, most MENA countries have focused their resources on 
large-scale supply-side initiatives such as desalination, dam construction, inter-basin water transfers, exploiting fossil groundwater aquifers, and importing virtual water. Because controlling water demand, increasing water efficiency, and encouraging conservation will be critical components in reacting to climate-induced impacts on the water sector, this paper examines the political, economic, and institutional variables that have impacted governance responses. While the research literature highlights the role of social capital in adaptive governance, we find that many MENA political leaders and water specialists seldom involve society actors in thinking about water hazards. As a result, researchers conclude that the critical skills for adaptive governance in the face of water constraints in the Middle East and North Africa are inadequate (Sowers, Vengosh, \& Weinthal, 2010).

Waste management is one of the most prominent environmental problems confronting Qatar. According to Zafar (2021), primarily due to rapid population increase, urbanization, industrial expansion, and economic expansion, the country has one of the highest per capita trash creation rates globally, generating 1.8 kilograms of rubbish each day. Qatar generates more than 2.5 million tons of municipal solid garbage every year. The majority of the solid waste stream comprises organic materials (about 60\%), with the remainder made up of recyclables such as glass, paper, metals, and plastics. However, the method of waste disposal by landfill is not a practical solution for a country like Qatar, where land availability is limited. Therefore, an alternative strategy was introduced, the solid waste management strategy. This study aims to mitigate such issues by spreading awareness and taking an action plan based on the given data. We are starting within the school and bringing the advocacy externally in the community.

According to the Qatar National Development Approach (2016), the government would implement a multifaceted strategy to reduce trash created by homes, commercial locations, and industry and encourage recycling efforts. Qatar plans to implement an integrated waste hierarchy comprising prevention, reduction, reuse, recycling, energy recovery, and landfill disposal as a last resort. To minimize the amount of garbage sent to the Umm Al-Afai landfill, five waste transfer stations have been established in South Doha, West Doha, the Industrial Area, Dukhan, and Al-Khor. These transfer stations have a material recovery facility for sorting recyclables, including glass, paper, aluminum, and plastic. This study is looking forward to promoting these strategies for the sake of awareness of the students and school employees.

In line with implementing a multifaceted strategy to reduce trash, AlMa'adeed et al. (2012) conducted a study wherein the Municipal solid waste management (MSWM) comprises the most vital wellbeing and ecological problem confronting experts in the Arabian Gulf. The investigation showed that Qatar delivered around 2,000,000 tons of solid municipal waste every year, compared to a day-by-day age rate per capita of around $2.5 \mathrm{~kg}$. Around $60 \%$ of MSW is a natural material, and around $300 \mathrm{~kg}$ is made day by day. Landfill and soil treatment are Qatar's most suitable garbage removal strategies. UmmAl-Afai landfill has almost $80 \%$ of MSW. Strategy producers have empowered reuse and recycling to reduce the interest in natural substances and diminish the amount of waste going to landfills. Hence, reusing is the supported answer for plastic waste administration since it ecologically affects the characterized sway classifications, from Global Warming Potential (GWP) and Human Toxicity Potentials (HTP) markers.

Furthermore, Bello (2018) supported this by the calculated average daily waste generated per capita is $1.135 \mathrm{~kg}$. The review concluded that the municipalities generally gather the household waste at no expense for the occupants, and most respondents do not sort their household waste before removal. With a Pearson Correlation coefficient worth 0.305 at 0.05 critical level, the review showed a moderate positive connection between family size and waste produced. Another financial way of life factors, such as pay level, schooling element, and age, did not demonstrate a vast relationship with strong city waste nearby.

Environmentalism Relationships with nature and society influence society's pro-environmental behavior. Participants in the worldwide climate strike requested that international leaders strengthen environmental legislation, eliminate government subsidies to the fossil fuel sector, and invest in the infrastructure needed to transition to 100 percent renewable energy as soon as possible. Months later, individuals worldwide continue to take to the streets favor environmental sustainability. Global warming and pollution are frequently depicted as concerns directly affecting individual customers. However, environmentalists contend that being green is difficult, if not impossible, when renewable energy sources, dependable public transit, and environmentally friendly product alternatives are difficult to locate - and frequently challenging to buy even when accessible. Protesting in favor of systemic change and changing your consumption patterns by taking the bus or investing in a reusable shopping bag may appear to come under the banner of "environmentalism" on the surface. However, psychology science has discovered that the variables that inspire people to participate in pro-environmental 
consumption in their personal lives and take political action in society differ substantially. According to research, our willingness to participate in these activities reflects not only how we identify as members of our social and political ecosystems but also how we envision our relationship with nature itself — and that the relative importance of each of these relationships varies significantly across cultures (Armstrong, 2019).

Previous studies indicate that children who participate in local community initiatives are better equipped to learn about and connect with environmental challenges. Students may witness the difficulties directly and are given the impression that they can affect local results. In the study conducted by Burke (2018), 147 students completed questionnaires before attending the environmental fair and after. After the expo, all students' intentions to become active with local environmental groups increased statistically significantly. The study looked at students' self-reported environmental knowledge and willingness to become active, which means they may have misled themselves on the questionnaire, either intentionally or accidentally. This also implies that the researcher did not gather data on whether students followed through on their plans to get active or were inspired.

Further study might be conducted by following up with kids long after the fair to see if they had become interested in environmental organizations. The findings highlight the gap between awareness and action that prior research has shown. The fact that awareness was not substantially connected to joining an environmental group suggests that the fair's impact component was something other than information provision. The author hypothesizes that one-on-one interactions with persons who work on environmental concerns infused the themes with "passion and energy," inspiring pupils. Because of the considerable improvements in students' intentions to become active with community groups, the author recommends that other school districts replicate this idea for their communities. This is most likely to be helpful for students who have a relatively low level of environmental awareness.

In Israel, youth movements are non-formal organizations that educate young people about social and political issues and give a broad platform for them to participate in their communities. Goldman et al. (2015) looked into whether adolescent social activism, which includes involvement in youth movements and a leadership role in instructing younger members, is also reflected in environmental activism. Environmental literacy variables revealed that youth are only generally knowledgeable about environmental problems, express 'technical-optimism,' which leads to little concern for the environment, show limited recognition of the importance of environmental education, and show limited recognition of the necessity for changes in personal consumerism in a survey of 1496 young instructors drawn from 15 official youth movements. Environmental issues are also not on their minds, according to the findings, because they are not a topic of conversation with classmates or family. Nonetheless, these adolescents have high self-confidence in their ability to affect change, see themselves as role models for younger members, and exhibit a willingness to incorporate environmentally-friendly activities into regular youth movement events. Their appreciation of nature also serves as a basis for developing other environmental values. Further investigation reveals how these findings can provide theoretical and practical tools for incorporating sustainability into the youth movement framework and help them achieve their potential for promoting sustainability in society.

It is crucial to encourage pro-environmental behavior to decrease environmental consequences and progress toward a more sustainable future. According to Heyl et al. (2013), higher education has an essential role in preparing professionals who will play an essential part in environmental protection in the future. Education is crucial because education is implicitly founded on the assumption that people's ideas about the environment are the core causes of environmental issues. The study also mentioned that environmental education might affect environmental behavior. Teaching allows for developing a good attitude, accepting responsibility, and participation in protecting and conserving the environment. Furthermore, it has been discovered that environmental education influences the interactions between the community and natural resources when combined with environmental legislation. Finally, the researchers' study determined whether there are substantial differences between college students based on their degrees of specialization, whether or not they are connected to the environment, the year in which they are studying, and gender.

The study's findings imply that, on average, university undergraduate engineering students have good environmental views, as evidenced by earlier studies with third-year students. Benefits are accurately believed to impact the environment positively, and pro-environmental actions are present on a behavioral level, though infrequently. Recycling, water, and energy usage, on the other hand, are associated with better average scores on environmental views among generalized sample students. Similarly, the mentioned behaviors are most commonly noticed regarding water and energy use, whereas those linked to responsible consumption and involvement are the least frequently observed. Overall, students exhibit favorable environmental views, but this is not reflected in a comparable or proportionate regularity of participating in the environmental 
activity, particularly in the categories relating to responsible consumption and involvement. Following a regression analysis, the three factors: effort, attitude, and consequences, are shown to predict the frequency of pro-environmental activities.

Sustainable Practices According to Jacobsen et al. (2020), there are four categories of sustainability practices: inspiring and informing, productizing, co-creating, and ecosystem building. The researchers incorporated such findings into a sustainability maturity typology, proposing that the previously stated four practices are associated with increasing intensity of sustainability intention, resulting in firms achieving higher levels of sustainability in the focal business practices as they progress from inspiring and informing to system building. This study did not identify substantial variations in involvement with sustainable practices across small and more significant businesses or industries. As a conclusion of the study of these researchers, there is no generic "one-size-fits-all" strategy to support sustainable practices since approaches must be tailored to a firm's level of sustainability maturity.

According to Richer (2009), Qatar is at present during the time spent fostering a reasonable arrangement of supportable advancement markers for the nation, including social, financial, and natural pointers. These pointers depend on information gathered from 2000-2005 and show clear patterns in friendly, monetary, and ecological regions. Social markers incorporate a proportion of social administrations that sway the way of life of the populace, for example, the arrangement of medical care administrations and instruction. Financial pointers incorporate parts of actual monetary construction, for instance, the macroeconomic performance, just as the proportion of gender equality correspondence and utilization (squander creation). Ecological pointers incorporate air quality estimation, land corruption, water amount and quality, and biodiversity. The patterns seen in these pointers are varied. For instance, throughout 2000-2005, compost utilization stayed about something very similar, and pesticide utilization diminished somewhat. Notwithstanding, the fish get multiplied practically while secured regions have expanded significantly.

As a result of the rising population, the educational sector is rapidly expanding. To combat its increasing carbon emissions and depletion of nonrenewable energy resources, energy efficiency strategies have been designed to increase the energy efficiency of school facilities worldwide. According to AlFaris et al. (2016), a tailored energy management program for one of the UAE's schools has allowed the researchers to conclude based on automated hourly thermal simulation. As the case demonstrates that energy efficiency could be enhanced by 35 percent, the audited school's energy usage index decreased from $438 \mathrm{kWh} / \mathrm{m} 2 /$ year to $285 \mathrm{kWh} / \mathrm{m} 2 /$ year after implementing the energy management program, presenting the suggested energy management scheme as a sequential and linear evolution. Hence, their methodology emphasizes the need for various methods to reduce carbon emissions by addressing sustainability's economic, environmental, and social components.

The notion of sustainability is essential to the environmental and development challenges and how governments, businesses, and environmental groups respond to them. Green Development offers a comprehensive and cohesive overview of sustainable development theory and practice. Green Development investigates the origins and growth of mainstream thought about sustainable development and provides a critique of the principles that underpin it. It bridges the gap between theory and reality by delving into the causes of environmental deterioration and development consequences. It contends that, in the end, 'green' development must be about political economics and power distribution rather than environmental quality. The political ecology of development, market-based and neoliberal environmentalism, and degrowth have all received increased attention (Adams, 2019).

Previous qualitative research has highlighted generativity and identity formation themes in interviews with environmental activists (Chan, 2009; Horwitz, 1996), implying their relevance as motivations for environmental conduct. Matsuba et al.'s (2012) study aim to build on their previous work by identifying clear correlations between identity maturity, generativity, and environmentalism using quantitative methods. The researchers designed quasi-experimental and correlational experiments to investigate the correlations. Fifty-four environmental activists were recruited, as were fifty-six comparison participants. Half of them were youth (mean age: twenty-two years) and half midlife adults (mean age: forty-three years). Sixty-three percent of those in our sample were female. Participants answered surveys on the environment, generativity, and identity. According to the study, activists, and comparison, persons varied on identity maturity, generativity, and environmental variables in general.

Furthermore, higher levels of identity maturity and generativity were linked to higher levels of environmental participation. Generativity was found to mediate the relation between identity maturity and environmentalism. The findings of their study suggest that engaging in generative behaviors may be an essential part of the process of forming an environmental identity and engaging in environmental actions. 
The continued pursuit of the more responsible implementation of the principles of sustainable development in the public and private sectors, particularly in general education schools, is necessitated by the already scarce and further dwindling natural resources, increasing environmental pollution, and other environmental, economic, and social challenges that transcend national boundaries. Raudeliūnienè et al. (2020) report that implementing knowledge management strategies in general education institutions is one of the most effective approaches to achieving sustainable development principles and positive social and economic results. The study assessed the unique characteristics of using knowledge management strategies in general education institutions for long-term growth, scientific literature analysis, multiple-criteria assessment, survey, and expert review. They were revealed that general education institutions have much potential for applying knowledge management approaches to achieve sustainable growth. Meanwhile, general education schools continued to struggle with a lack of teacher motivation and financial resources to implement knowledge management methods and develop knowledge infrastructure for long-term sustainability.

\subsection{Conceptual Framework}

\section{Input}

1. The demographic profile of the respondents in
terms of:
1.1 age;
1.2 sex; and
1.3 grade level?
2. Before the three-stage-plan, how many
respondents are aware of the following sustainable
practices in PSD:
2.1 Elite Paper Recycling;
2.2 No to Single-Use Plastic Advocacy; and,
2.3 C-Patrol and Doha Bank Eco-Schools?
3. After the three-stage-plan, how many
respondents are aware of the following sustainable
practices in PSD:
3.1 Elite Paper Recycling;
3.2 No to Single-Use Plastic Advocacy; and,
3.3 C-Patrol and Doha Bank Eco-Schools?
4. Before the three-stage-plan, how many
respondents comply with:
4.1 Elite Paper Recycling;
4.2 No to Single-Use Plastic Advocacy; and,
4.3 C-Patrol and Doha Bank Eco-Schools?
5. After the three-stage-plan, how many
respondents comply with:
5.1 Elite Paper Recycling;
5.2 No to Single-Use Plastic Advocacy; and,
5.3 C-Patrol and Doha Bank Eco-Schools?

Process

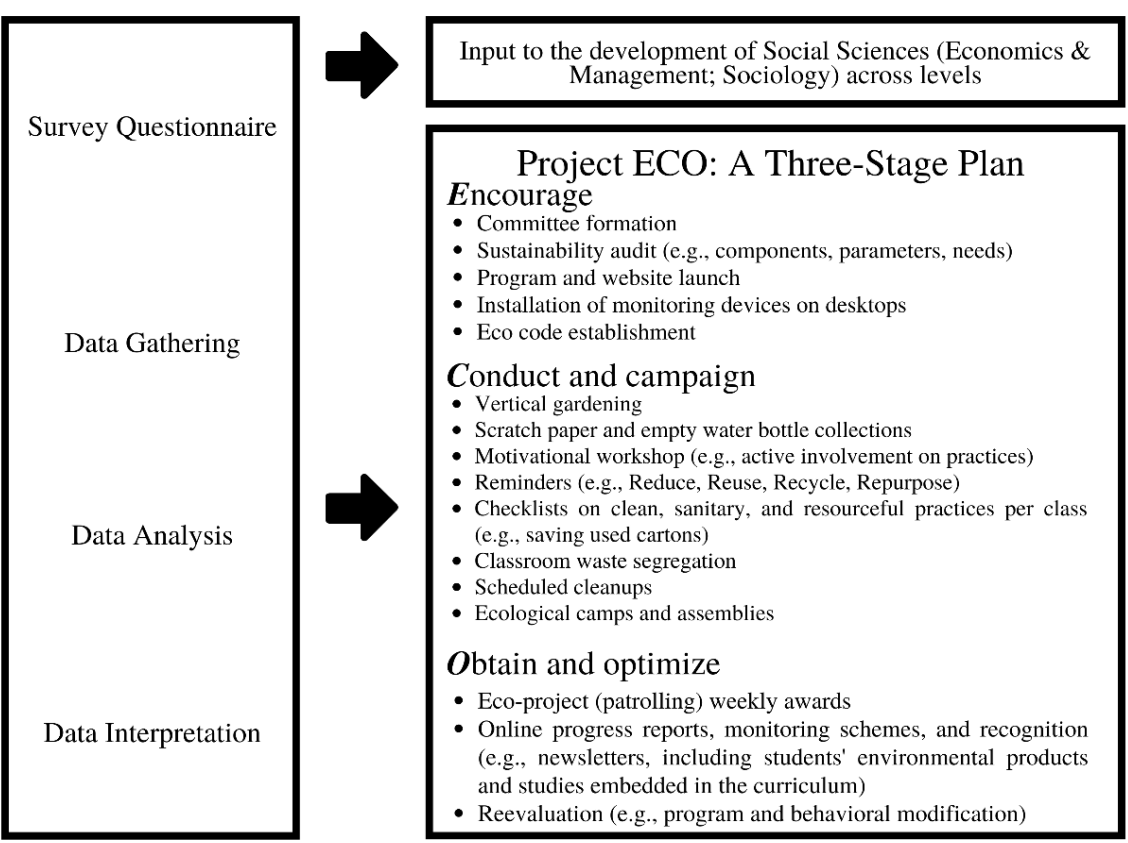

Figure 1: IPO Framework

Figure 1 shows the Conceptual Framework of the study. The Input-Process-Output (IPO) approach was used. As shown in the diagram above, the first frame contains the Input. The inputs of the study include the demographic profile of the respondents in terms of age, sex, and grade level, the awareness of the respondents on the sustainable practices in PSD before and after the three-stages plan, and the compliance of the respondents with the sustainable practices before and after the threestage-plan. The second frame contains the process. This study used the distribution of survey questionnaires through Google Forms, gathering data, analysis of data, and interpretation of data, resulting in the output. The results were a proposal regarding the Input to the development of Social Sciences (Environmental Science) across levels and a program titled 'Project ECO: A Three-Stage Plan' showcasing the three stages: Encourage, Conduct and campaign, and Obtain and optimize. The first stage is Encourage, where a committee was formed for a sustainability audit. A program and website were launched, installing monitoring devices on desktops and eco code establishment to ensure readiness and purpose. The second stage is Conduct and campaign, where implementation occurred through vertical gardening, scratch paper, water bottle collections, motivational workshops, reminders, checklists on clean, sanitary, and resourceful practices per class, and classroom waste segregation. Events like scheduled cleanups and ecological camps and assemblies will also be executed. The last stage is Obtain and optimize. The Eco-project weekly awards and online progress reports, monitoring schemes, and recognition and reevaluation are done to monitor objectives and set new goals. 


\section{Methods}

\subsection{Research Design}

The study utilized the descriptive design of research. According to McCombes (2019), descriptive research accurately describes a population, situation, or phenomenon. Therefore, descriptive research is the most suitable research design to come across the research objective, which is to gather the necessary data of 190 respondents to describe the measurable impact of sustainable practices of Philippine School Doha on the students' move towards youth environmentalism. Moreover, the study used a quantitative method, wherein the data were collected through survey questionnaires.

\subsection{Research Locale}

The study took place in Doha, Qatar, specifically in Philippine School Doha.

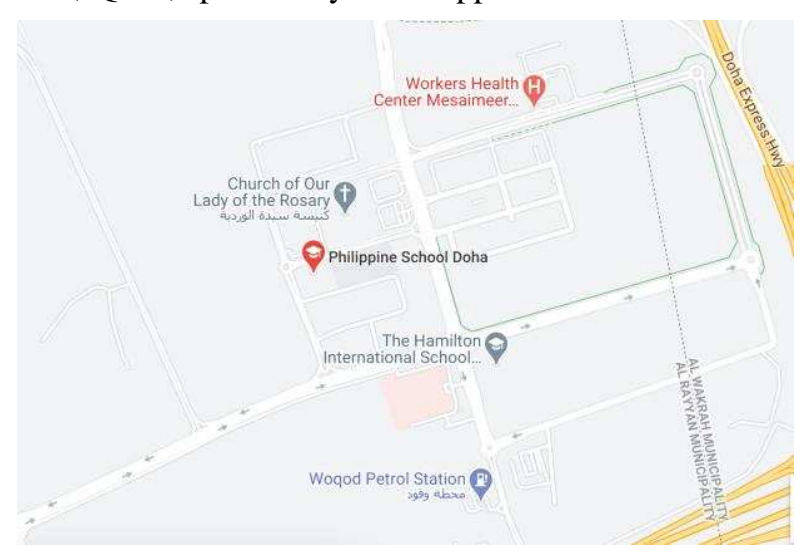

Figure 2: Map of Philippine School Doha

Retrieved from: Google Maps (2021), Map of Philippine School Doha

\subsection{Research Respondents}

This research described the measurable impact of sustainable practices of Philippine School Doha on the students' move towards youth environmentalism. The population of this study includes the Senior High School students, specifically those from Grade 11 to Grade 12 enrolled in Philippine School Doha for the S.Y. 2021-2022. This study also utilized the simple random sampling technique. Using Slovin's formula, 190 respondents are included as the sample in this study from 334 students in the Senior High School Department.

\subsection{Research Instrument}

The researchers developed a self-made questionnaire for the Senior High School students in Philippine School Doha to meet the study's objectives. The questionnaires were composed of close-ended questions. The questionnaire is divided into three parts. The first part is about the respondents' demographic profile, the second part is about the sustainable practices in PSD that they are aware of, and the third part is the respondents' compliance with the sustainable practices. These questions were formulated based on different literature and studies related to the impact of sustainable practices on the students' move towards youth environmentalism.

\subsection{Data Gathering Procedure}

The data were collected in the following manner: First, the total number of Senior High School students for the S.Y. 2021-2022 was asked from the Senior High School presidents of each section. Second, permission to conduct the study was obtained from the Senior High School Vice Principal. The third step was the actual administration of the developed instrument to the respondents through Google Forms. Finally, the data were carefully tallied and analyzed. 
2.6 Methods of Scoring and Interpretation

Slovin's formula, percentage, frequency, weighted mean, and standard deviation are the statistical tools applied to the collected data to determine the answers posted. First, Slovin's formula was used to determine the sample size needed in this study. Second, percentages and frequency were used to calculate the demographic profile and awareness of the respondents. Lastly, weighted mean and standard deviation were used to precisely determine the respondents' compliance with these sustainable practices.

\subsection{Statistical Treatment}

\section{Percentage}

$$
\begin{aligned}
& \mathrm{P}=\mathrm{f} / \mathrm{n} \times 100 \% \\
& \text { Where: } \\
& \mathrm{P}=\text { percentage } \\
& \mathrm{f}=\text { frequency of responses } \\
& \mathrm{n}=\text { total number of respondents }
\end{aligned}
$$

Weighted Mean$$
W M=\underline{5 f+4 f+3 f+2 f+f}
$$

Where:

$\mathrm{WM}=$ weighted mean

$\mathrm{f}=$ frequency

$\mathrm{n}=$ total number of respondents

Standard Deviation

$$
\sqrt{\frac{1}{N-1} \sum_{i=1}^{N}\left(x_{i}-\bar{x}\right)^{2}},
$$

Slovin's Formula

$$
n=\frac{N}{1+N e^{2}}
$$

Where:

$\mathrm{n}=$ sample size

$\mathrm{N}=$ total population size

$\mathrm{e}=$ margin of error

\section{Results}

\subsection{Table 1}

Table 1. The Demographic Profile of the Respondents in Terms of Age

\begin{tabular}{lll}
\hline Age & Frequency & Percentage $(\%)$ \\
\hline 15 years old and below & 6 & $3 \%$ \\
$16-17$ years old & 145 & $76 \%$ \\
18 years old and above & 39 & $21 \%$ \\
Total & $\mathbf{1 9 0}$ & $\mathbf{1 0 0 \%}$ \\
\hline
\end{tabular}

Table 1 exhibits the demographic profile of the students according to their age. It shows that 190 respondents were included in this research. Out of 190 respondents, there are 6 or $3 \%$ with the age of 15 and below, 145 or $76 \%$ with the age of 16 to 17 , and 39 or $21 \%$ with the age of 18 and above.

Table 2. The Demographic Profile of the Respondents in Terms of Sex

\begin{tabular}{lll}
\hline Sex & Frequency & Percentage (\%) \\
\hline Female & 95 & $50 \%$ \\
Male & 95 & $50 \%$ \\
Total & $\mathbf{1 9 0}$ & $\mathbf{1 0 0 \%}$ \\
\hline
\end{tabular}


Table 2 exhibits the demographic profile of the respondents according to their sex. Out of 190 respondents, 95 or $50 \%$ are females and 95 or $50 \%$ are males.

Table 3. The Demographic Profile of the Respondents in Terms of Grade Level

\begin{tabular}{lll}
\hline Grade Level & Frequency & Percentage (\%) \\
\hline Grade 11 & 94 & $49 \%$ \\
Grade 12 & 96 & $51 \%$ \\
Total & $\mathbf{1 9 0}$ & $\mathbf{1 0 0 \%}$ \\
\hline
\end{tabular}

Table 3 exhibits the demographic profile of the respondents according to their grade level. Out of 190 respondents, 94 or $49 \%$ are grade 11 and 96 or $51 \%$ are grade 12 .

Table 4. The Awareness of the Respondents on the Sustainable Practices in PSD Before the Three-Stage-Plan

\begin{tabular}{lll}
\hline Sustainable Practice & Frequency & Percentage (\%) \\
\hline Elite Paper Recycling & 33 & $17 \%$ \\
No to Single-Use Plastic Advocacy & 36 & $19 \%$ \\
C-Patrol and Doha Bank Eco-Schools & 6 & $3 \%$ \\
Elite Paper Recycling and No to Single-Use Plastic Advocacy & 43 & $23 \%$ \\
Elite Paper Recycling and C-Patrol and Doha Bank Eco-Schools & 7 & $4 \%$ \\
No to Single-Use Plastic Advocacy and C-Patrol and Doha Bank Eco- & 16 & $8 \%$ \\
Schools & & \\
All & 28 & $15 \%$ \\
None & 21 & $11 \%$ \\
Total & $\mathbf{1 9 0}$ & $\mathbf{1 0 0 \%}$ \\
\hline
\end{tabular}

Table 4 exhibits the respondents' awareness of the sustainable practices in PSD before the three-stage plan. Out of 190 respondents, 33 or $17 \%$ are only aware of Elite Paper Recycling, 36 or 19\% are only aware of No to Single-Use Plastic Advocacy, and 6 or 3\% are only aware of C-Patrol and Doha Bank Eco-Schools. Additionally, 43 or 23\% are aware of Elite Paper Recycling, and No to Single-Use Plastic Advocacy, 7 or $4 \%$ are aware of Elite Paper Recycling and C-Patrol and Doha Bank Eco-Schools, and 16 or $8 \%$ are aware of No to Single-Use Plastic Advocacy and C-Patrol and Doha Bank EcoSchools. While 28 or $15 \%$ are aware of all three sustainable practices and 21 or $11 \%$ are unaware of any.

Table 5. The Awareness of the Respondents on the Sustainable Practices in PSD After the Three-Stage-Plan

\begin{tabular}{lll}
\hline Sustainable Practice & Frequency & Percentage (\%) \\
\hline Elite Paper Recycling & 33 & $17 \%$ \\
No to Single-Use Plastic Advocacy & 36 & $19 \%$ \\
C-Patrol and Doha Bank Eco-Schools & 14 & $\mathbf{7 \%}$ \\
Elite Paper Recycling and No to Single-Use Plastic Advocacy & 44 & $23 \%$ \\
Elite Paper Recycling and C-Patrol and Doha Bank Eco-Schools & 8 & $4 \%$ \\
No to Single-Use Plastic Advocacy and C-Patrol and Doha Bank Eco- & 11 & $6 \%$ \\
Schools & & \\
All & 37 & $20 \%$ \\
None & 7 & $4 \%$ \\
Total & $\mathbf{1 9 0}$ & $\mathbf{1 0 0 \%}$ \\
\hline
\end{tabular}

Table 5 exhibits the respondents' awareness of the sustainable practices in PSD after the three-stage plan. Out of 190 respondents, 33 or $17 \%$ are only aware of Elite Paper Recycling, 36 or 19\% are only aware of No to Single-Use Plastic Advocacy, and 14 or $7 \%$ are only aware of C-Patrol and Doha Bank Eco-Schools. Additionally, 44 or 23\% are aware of Elite Paper Recycling, and No to Single-Use Plastic Advocacy, 8 or $4 \%$ are aware of Elite Paper Recycling and C-Patrol and Doha Bank Eco-Schools, and 11 or 6\% are aware of No to Single-Use Plastic Advocacy and C-Patrol and Doha Bank EcoSchools. While 37 or $20 \%$ are aware of all three sustainable practices and 7 or $4 \%$ are unaware of any.

Table 6. The Compliance of the Respondents with Elite Paper Recycling Before the Three-Stage-Plan

\begin{tabular}{llll}
\hline Statements & WM & SD & VI \\
\hline 1. I use waste cartons and trays from the recycling cage for my projects. & 2.8 & 0.8 & Often \\
2. I put used cardboard and paper in the recycling cage. & 2.8 & 1 & Often
\end{tabular}


3. To maximize our resources, I get materials from the recycling cage.

4. I take the initiative to make the recycling cage look presentable.

5. I ensure that the recyclable cardboard and paper maintain good quality.

Total
2.8

2.2

2.7

2.66
Often

Rarely

Often

Often

\section{Legend:}

WM Weighted Mean

SD Standard Deviation

VI Verbal Interpretation

1-1.75 Never

1.76-2.50 Rarely

2.51-3.25 Often

3.26-4.00 Always

Table 6 shows the respondents' compliance with Elite Paper Recycling before the three-stage plan. The statements 'I use waste cartons and trays from the recycling cage for my projects,' 'I put used cardboard and paper in the recycling cage,' and 'To maximize our resources, I get materials from the recycling cage' got the highest weighted mean of 2.8 that is verbally interpreted as often, with standard deviations of $0.8,1$, and 0.9 respectively. It is followed by the statement 'I ensure that the recyclable cardboard and paper maintain good quality,' which got a weighted mean of 2.7 that is verbally interpreted as often, with a standard deviation of 1. Lastly, the statement 'I take the initiative to make the recycling cage look presentable' got a weighted mean of 2.2 that is verbally interpreted as rarely, with a standard deviation of 0.9. The overall weighted mean of Table 6, which discusses the respondents' compliance with Elite Paper Recycling, is 2.66 and is verbally interpreted as often.

Table 7. The Compliance of the Respondents with No to Single-Use Plastic Advocacy Before the Three-Stage-Plan

\begin{tabular}{|c|c|c|c|}
\hline Statements & WM & SD & VI \\
\hline 1. I use a metal straw instead of a disposable drinking straw. & 2.2 & 1.1 & Rarely \\
\hline 2. I bring reusable utensils for my meals at school. & 3.4 & 0.8 & Always \\
\hline 3. I use my water bottle instead of a disposable plastic water bottle. & 3.2 & 1 & Often \\
\hline 4. I use my silver or stainless steel cutleries instead of disposable plastic cutleries. & 3.6 & 0.7 & Always \\
\hline Total & 3.06 & & Often \\
\hline
\end{tabular}

Legend:

WM Weighted Mean

SD Standard Deviation

VI Verbal Interpretation

1-1.75 Never

1.76-2.50 Rarely

2.51-3.25 Often

3.26-4.00 Always

Table 7 shows the respondents' compliance with No to Single-Use Plastic Advocacy before the three-stage plan. The statement 'I use my silver or stainless steel cutleries instead of disposable plastic cutleries' got the highest weighted mean of 3.6 that, is verbally interpreted as always, with a standard deviation of 0.7. Next, the statement 'I bring reusable utensils for my meals at school' got a weighted mean of 3.4 that can be verbally interpreted as always, with a standard deviation of 0.8 . It is followed by the statement 'I use my water bottle instead of a disposable plastic water bottle,' which got a weighted mean of 3.2 that is verbally interpreted as often, with a standard deviation of 1 . Then, the statement 'I recycle plastic waste for class projects and contests' got a weighted mean of 2.9 that is verbally interpreted as often, with a standard deviation of 1. Lastly, the statement 'I use a metal straw instead of a disposable drinking straw' got a weighted mean of 2.2 that is verbally interpreted as rarely, with a standard deviation of 1.1 . The overall weighted mean of Table 7 , which discusses the respondents' compliance with No to Single-Use Plastic Advocacy, is 3.06 and is verbally interpreted as often.

Table 8. The Compliance of the Respondents with C-Patrol and Doha Bank Eco-Schools Before the Three-Stage-Plan

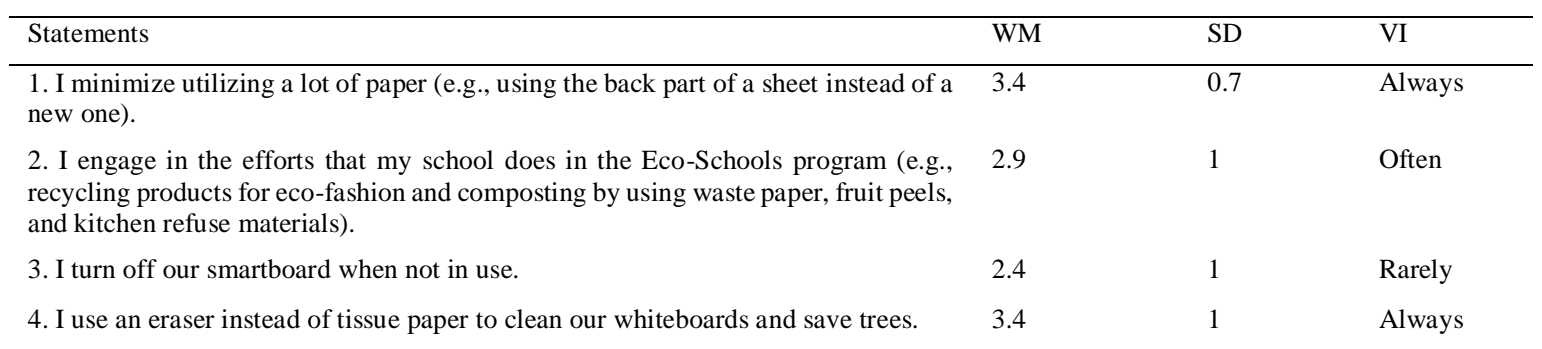


5. To save, I store and reuse scratch papers for projects and tasks.

3.4

3.10
Always

Often

\section{Legend: \\ WM Weighted Mean \\ SD Standard Deviation \\ VI Verbal Interpretation \\ 1-1.75 Never \\ 1.76-2.50 Rarely \\ 2.51-3.25 Often \\ 3.26-4.00 Always}

Ttable 8 shows the respondents' compliance with C-Patrol and Doha Bank Eco-Schools before the three-stage plan. The statements 'I minimize utilizing much paper (e.g., using the back part of a sheet instead of a new one),' 'I use an eraser instead of tissue paper to clean our whiteboards and save trees,' and 'To save, I store and reuse scratch papers for projects and tasks' got the highest weighted mean of 3.4 that is verbally interpreted as always, with standard deviations of 0.7 , 1 , and 1 respectively. Then, the statement 'I engage in the efforts that my school does in the Eco-Schools program (e.g., recycling products for eco-fashion and composting by using waste paper, fruit peels, and kitchen refuse materials)' got a weighted mean of 2.9 that is verbally interpreted as often, with a standard deviation of 1. Lastly, the statement 'I turn off our smartboard when not in use' got a weighted mean of 2.4 that is verbally interpreted as rarely, with a standard deviation of 1 . The overall weighted mean of Table 8, which discusses the respondents' compliance with C-Patrol and Doha Bank Eco-Schools, is 3.10 and is verbally interpreted as often.

Table 9. The Compliance of the Respondents with Elite Paper Recycling After the Three-Stage-Plan

\begin{tabular}{|c|c|c|c|}
\hline Statements & WM & SD & VI \\
\hline 1. I use waste cartons and trays from the recycling cage for my projects. & 2.9 & 0.8 & Often \\
\hline 2. I put used cardboard and paper in the recycling cage. & 2.7 & 0.9 & Often \\
\hline 3. To maximize our resources, I get materials from the recycling cage. & 2.9 & 0.9 & Often \\
\hline 4. I take the initiative to make the recycling cage look presentable. & 2.3 & 1 & Rarely \\
\hline Total & 2.70 & & Often \\
\hline
\end{tabular}

Legend:

WM Weighted Mean

SD Standard Deviation

VI Verbal Interpretation

1-1.75 Never

1.76-2.50 Rarely

2.51-3.25 Often

3.26-4.00 Always

Table 9 shows the respondents' compliance with Elite Paper Recycling after the three-stage plan. The statements 'I use waste cartons and trays from the recycling cage for my projects,' and 'To maximize our resources, I get materials from the recycling cage' got the highest weighted mean of 2.9 that is verbally interpreted as often, with standard deviations of 0.8 and 0.9 respectively. It is followed by the statements 'I put used cardboard and paper in the recycling cage,' and 'I ensure that the recyclable cardboard and paper maintain good quality,' which got a weighted mean of 2.7 that is verbally interpreted as often, with standard deviations of 0.9 and 1 respectively. Lastly, the statement 'I take the initiative to make the recycling cage look presentable' got a weighted mean of 2.3 that is verbally interpreted as rarely, with a standard deviation of 1 . The overall weighted mean of Table 9, which discusses the respondents' compliance with Elite Paper Recycling, is 2.70 and is verbally interpreted as often. Based on the study conducted by Badea et al. (2020), students in educational institutions have their perceptions of environmental approaches because of the different levels of knowledge, attitude, and practice towards sustainable consumption. This study supports the statement that the respondents' compliance with the sustainable practices in PSD leaves a significant impact on the student's move towards youth environmentalism.

Table 10. The Compliance of the Respondents with No to Single-Use Plastic Advocacy After the Three-Stage-Plan

\begin{tabular}{llll}
\hline Statements & WM & SD & VI \\
\hline 1. I use a metal straw instead of a disposable drinking straw. & 2.3 & 1.1 & Rarely \\
2. I bring reusable utensils for my meals at school. & 3.4 & 0.9 & Always \\
3. I use my water bottle instead of a disposable plastic water bottle. & 3.3 & 0.9 & Always \\
4. I use my silver or stainless steel cutleries instead of disposable plastic cutleries. & 3.5 & 2.9 & 0.9 \\
5. I recycle plastic waste for class projects and contests. & $\mathbf{3 . 0 8}$ & Often \\
Total & & Often \\
\hline
\end{tabular}




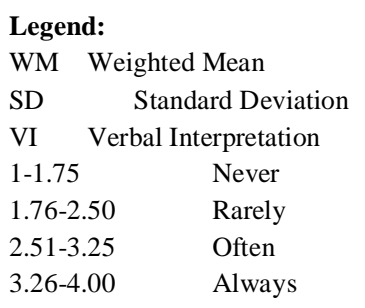

Table 10 shows the respondents' compliance with No to Single-Use Plastic Advocacy after the three-stage plan. The statement 'I use my silver or stainless steel cutleries instead of disposable plastic cutleries' got the highest weighted mean of 3.5 that is verbally interpreted as always, with a standard deviation of 0.9. Next, the statement 'I bring reusable utensils for my meals at school' got a weighted mean of 3.4 that can be verbally interpreted as always, with a standard deviation of 0.9 . It is followed by the statement 'I use my water bottle instead of a disposable plastic water bottle,' which got a weighted mean of 3.3 that is verbally interpreted as always, with a standard deviation of 0.9 . Then, the statement 'I recycle plastic waste for class projects and contests' got a weighted mean of 2.9 that is verbally interpreted as often, with a standard deviation of 0.9 . Lastly, the statement 'I use a metal straw instead of a disposable drinking straw' got a weighted mean of 2.3 that is verbally interpreted as rarely, with a standard deviation of 1.1. The overall weighted mean of Table 10, which discusses the respondents compliance with No to Single-Use Plastic Advocacy, is 3.08 and is verbally interpreted as often. Based on the study conducted by Badea et al. (2020), students in educational institutions have their perceptions of environmental approaches because of the different levels of knowledge, attitude, and practice towards sustainable consumption. This study supports the statement that the respondents' compliance with the sustainable practices in PSD leaves a significant impact on the student's move towards youth environmentalism.

Table 11. The Compliance of the Respondents with C-Patrol and Doha Bank Eco-Schools After the Three-Stage-Plan

\begin{tabular}{llll}
\hline Statements & WM & SD & VI \\
\hline $\begin{array}{l}\text { 1. I minimize utilizing a lot of paper (e.g., using the back part of a sheet instead of a } \\
\text { new one). }\end{array}$ & 3.4 & 0.6 & Always \\
$\begin{array}{l}\text { 2. I engage in the efforts that my school does in the Eco-Schools program (e.g., } \\
\text { recycling products for eco-fashion and composting by using waste paper, fruit peels, } \\
\text { and kitchen refuse materials). }\end{array}$ & & & Often \\
3. I turn off our smartboard when not in use. & 2.8 & & \\
4. I use an eraser instead of tissue paper to clean our whiteboards and save trees. & 3.5 & 1 & Often \\
5. To save, I store and reuse scratch papers for projects and tasks. & 3.5 & 0.8 & Always \\
Total & $\mathbf{3 . 2 2}$ & & Always \\
\hline
\end{tabular}

Legend:

WM Weighted Mean

SD Standard Deviation

VI Verbal Interpretation

1-1.75 Never

1.76-2.50 Rarely

2.51-3.25 Often

3.26-4.00 Always

Table 11 shows the respondents' compliance with C-Patrol and Doha Bank Eco-Schools after the three-stage plan. First, the statements 'I use an eraser instead of tissue paper to clean our whiteboards and save trees,' and 'To save, I store and reuse scratch papers for projects and tasks' got the highest weighted mean of 3.5 that is verbally interpreted as always, with standard deviations of 0.8 and 0.7 respectively. Then, the statement 'I minimize utilizing a lot of paper (e.g., using the back part of a sheet instead of a new one)' had a weighted mean of 3.4 that is verbally interpreted as always, with a standard deviation of 0.6 . Next, the statement 'I engage in the efforts that my school does in the Eco-Schools program (e.g., recycling products for eco-fashion and composting by using waste paper, fruit peels, and kitchen refuse materials)' got a weighted mean of 2.9 that is verbally interpreted as often, with a standard deviation of 0.9 . Lastly, the statement 'I turn off our smartboard when not in use' got a weighted mean of 2.8 that is verbally interpreted as often, with a standard deviation of 1 . The overall weighted mean of Table 11, which discusses the respondents' compliance with C-Patrol and Doha Bank Eco-Schools, is 3.22 and is verbally interpreted as often. Based on the study conducted by Badea et al. (2020), students in educational institutions have their perceptions of environmental approaches because of the different levels of knowledge, attitude, and practice towards sustainable consumption. This study supports the statement that the respondents' compliance with the sustainable practices in PSD leaves a significant impact on the student's move towards youth environmentalism.

\section{Discussion}

\subsection{Conclusions}

The findings based on the statistical analysis of data lead to the following conclusions:

1. The senior high school students for the school year 2021-2022 of Philippine School Doha are generally reliable sources of information needed for the study. 
a. The age of the respondents ranges from 15 to 18 years old.

b. The respondents are distributed equally between males and females, providing non-gendered bias.

c. The grade level of the respondents ranges from grades 11 and 12 .

2. Before the three-stage plan, results imply that 169 or $89 \%$ of senior high school students are aware of the sustainable practices in PSD.

a. 111 or $58 \%$ of the respondents are aware of Elite Paper Recycling.

b. 123 or $65 \%$ of the respondents are aware of No to Single-Use Plastic Advocacy.

c. 57 or $30 \%$ of the respondents know C-Patrol and Doha Bank Eco-Schools.

3. After the three-stage plan, results imply that 183 or $96 \%$ of senior high school students are aware of the sustainable practices in PSD.

a. 122 or $64 \%$ of the respondents are aware of Elite Paper Recycling.

b. 128 or $67 \%$ of the respondents know No to Single-Use Plastic Advocacy.

c. 70 or $37 \%$ of the respondents know C-Patrol and Doha Bank Eco-Schools.

4. With all of the sustainable practices done 'Often' before the three-stage plan, it is interpreted that senior high school students comply with the sustainable efforts of the school, specifically targeting waste management, energy, and water conservation, with simple acts of recycling paper and plastics.

a. The senior high school students comply least with Elite Paper Recycling of the school as the total mean is 2.66 with the verbal interpretation of 'Often.' The lack of campaign and force of implementation were some factors that contributed to the students' inability to recognize the project.

b. The senior high school students sometimes comply with the No to Single-Use Plastic Advocacy of the school as the total mean 3.06 with the verbal interpretation of 'Often.' As they demonstrate consistency, surveillance and campaigns would enhance some aspects of this practice.

c. The senior high school students comply best with C-Patrol and Doha Bank Eco-Schools. The total mean is 3.10 with the verbal interpretation of 'Often.' Despite being unaware of this sustainable technique, the high compliance demonstrates students' initiative in protecting the environment.

5. With all of the sustainable practices done 'Often' after the three-stage plan, it is interpreted that more senior high school students comply with the sustainable efforts of the school, specifically targeting waste management, energy, and water conservation, with simple acts of recycling paper and plastics.

a. The senior high school students comply least with Elite Paper Recycling as the total mean is 2.70 with the verbal interpretation of 'Often.'

b. The senior high school students sometimes comply with the No to Single-Use Plastic Advocacy of the school as the total mean 3.08 with the verbal interpretation of 'Often.'

c. The senior high school students comply best with C-Patrol and Doha Bank Eco-Schools. The total mean is 3.22 with the verbal interpretation of 'Often.'

\subsection{Recommendations}

Based on the empirical findings of the study, the following are recommended.

1. The students should have more initiative in sustainability practices with or without criteria and acknowledgments. They could derive future projects and conduct action research from the sustainability practices aforementioned in this study. They could also engage with eco-friendly projects regardless of age, sex, or grade level.

2. According to the findings, most senior high school pupils are aware of and follow the school's sustainability measures. Although results were satisfactory, the researchers and future researchers can increase the number of respondents in the study to gain better results. Furthermore, future researchers can use this research to assist them if their research problem involves environmentalism and sustainability topics to spread awareness further. Future researchers could also find more partnerships to push the school to its fullest potential as an eco-school. With more collaborations, the school will achieve conservation and concretize environment-friendly projects.

3. School administrators may utilize this information to help instructors from many departments teach students about the importance of environmentalism and sustainable measures that can be used to promote sustainable development and raise awareness. Traditional methods of environmental education (EE) asserted that students needed to have good experiences and develop values to appreciate and protect the environment. At the same time, research and educational literature have increasingly recognized that raising awareness and having external experiences are not enough to lead to a more sustainable future. An extension of this vision of EE was to see the school not just as a teaching ground for environmental management but also as a display of effective EE practice for the community (Hardon et al., 2004). As aforementioned, teaching students does not have enough force to achieve the satisfactory impact of the sustainability practices; therefore, actions are needed. 
a. Elite Paper Recycling Teachers and school administrators should devote time to educate students regarding the school's sustainability practices. One ton (400 reams) of paper needs 24 trees, consumes 7000 gallons of water, and uses 380 gallons of oil (Johnson, 2017). In an environment that utilizes hoards of paper, the school community, especially the students, must know how to recycle and use the material at its maximum potential while learning. Some practices include saving scratch papers per classroom, utilizing the front and back of a paper, and returning the same carton boxes utilized for school projects in the Elite Paper Recycling cage. In return, the school will save five mature trees, 1730 gallons of water, 94 gallons of oil if all (99) classes reuse and recycle one ream of paper. The school's carbon footprint may also be lessened. The Environmental Protection Agency (EPA) has reported that life cycle emissions are avoided three times when mixed recyclable material is recycled rather than disposed of (2019).

b. No to Single-Use Plastic Advocacy School administrators should partner with others other than Elite Paper Recycling, such as Al Meera's recycling initiative, to further enhance the school's sustainability efforts. Teachers could enforce the 'No to Single-Use Plastics' by encouraging students to bring their water bottles. Disposable bottles often end up in our waterways, contaminating water for many years to come. To add more knowledge to this study, extending the advocacy to a set of plastics, other than forks and spoons, to have a broader range of factors.

c. C-Patrol and Doha Bank Eco-Schools Teachers should impose policies such as the 'clean as you go' to enhance students' initiative in helping the environment. They should be strict for better implementation of the projects resulting in the proper execution of the practices. It includes waste management of paper and plastics. One desktop uses 200 watts per hour. If one class' desktop use is lessened by one hour daily, the school will save approximately 4019 kilowatts per year, with all (99) classes participating for 203 school days.

\section{References}

[1] Adams, B. (2019, December 20). Green development | Environment and sustainability in a developing Wor. Taylor \& Francis. https://www.taylorfrancis.com/books/mono/10.4324/9780203929711/green-development-bill-adams

[2] AlFaris, F., et al. (2016). Improvement of efficiency through an energy management program as a sustainable practice in schools. Science Direct. https://www.sciencedirect.com/science/article/abs/pii/S0959652616308599

[3] AlMa'adeed, M., et al. (2012, March). An Overview of Solid Waste Management and Plastic Recycling in Qatar. Research Gate. https://www.researchgate.net/publication/251302635_An_Overview_of_Solid_Waste_Management_and_Plastic_Recycling_in_Qatar

[4] Armstrong, K. (2019, December 23). The social dynamics of environmentalism. Association for Psychological Science - APS. https://www.psychologicalscience.org/observer/the-social-dynamics-of-environmentalism

[5] Bello, H. (2018). Impact of Changing Lifestyle on Municipal Solid Waste Generation in Residential Areas: Case Study of Qatar. International Journal of Waste Resources. https://www.longdom.org/open-access/impact-of-changing-lifestyle-on-municipal-solid-waste-generation-inresidential-areascase-study-of-qatar-2252-5211-1000335.pdf

[6] Burke, A. M. (2018, January 31). Effects of exposure to environmental groups on student awareness of environmental issues and their desire to be locally involved. NAAEE. https://naaee.org/eepro/research/library/effects-exposure-environmental-groups

[7] Darwish, M. (2013, September 27). Towards energy conservation in Qatar. scirp.org. https://file.scirp.org/Html/5-2650044_40880.htm

[8] Dornob. (2014, October 16). Rubber Toilet Brick Can Save Billions of Gallons of Water. https://dornob.com/rubber-toilet-brick-can-save-billions-ofgallons-of-water/

[9] Elite Paper Recycling. (2019). Elite paper recycling | Carton box factory in Qatar. Using window.location to Redirect to a Different URL with JavaScript | appendTo. https://www.epr.qa/en/index.php

[10] Environmental Protection Agency. (2019). CARBON FOOTPRINT \& STRATEGY. Waste Management 2018 Sustainability Report. https://sustainability.wm.com/2018/operations/carbon-footprint

[11] Evans, M. (2020). 5 reasons we should care about saving water. The Balance Small Business. https://www.thebalancesmb.com/conservation-effortswhy-should-we-save-water-3157877

[12] Folk, E. (2021). Sustainability starts in the classroom. The Ecologist. https://theecologist.org/2021/jan/12/sustainability-starts-classroom

[13] Gabbar, H., Pokharel, S., Musharavati, F., \& Ayoub, N. (2014, December). Energy consumption and conservation practices in Qatar-A case study of a hotel building. ScienceDirect.com | Science, health and medical journals, full text articles and books. https://www.sciencedirect.com/science/article/abs/pii/S0378778814005908

[14] Goldman, D., Pe'er, S., Yavetz, B. (2015, November). Environmental literacy of youth movement members - is environmentalism a component of their social activism? Environmental Education Research. https://www.tandfonline.com/doi/abs/10.1080/13504622.2015.1108390 
[15] Heyl, M., Díaz, E. M., \& Cifuentes, L. (2013, July 14). Environmental attitudes and behaviors of college students: A case study conducted at a Chilean university. SciELO Colombia- Scientific Electronic Library Online. https://www.scielo.org.co/scielo.php?script=sci_arttext\&pid=S012005342013000300013

[16] Jacobsen, S. S., Korsgaard, S., \& Günzel-Jensen, F. (2020). Towards a Typology of Sustainability Practices: A Study of the Potentials and Challenges of Sustainable Practices at the Firm Level. https://file:///C:/Users/Angelina/Downloads/sustainability-12-05166-v2.pdf

[17] Johnson, B. (2017, September 16). How many trees does YOUR office use each month? Green Girl Recycling. https://www.greengirlrecycling.com/post/how-many-trees-does-your-office-use-each-month

[18] Matsuba, M.K, et al. (2012, June 29). Environmentalism as a Context for Expressing Identity and Generativity: Patterns Among Activists and Uninvolved Youth and Midlife Adults. Wiley Online Library. https://doi.org/10.1111/j.1467-6494.2012.00765.x

[19] McCombes, S. (2019, January 13). Descriptive research. Coursehero. https://www.coursehero.com/file/57428827/Descriptive-researchdocx/

[20] Mohammed, S. (2021, May 3). Water awareness in Qatar. EcoMENA. https://www.ecomena.org/water-awareness-in-qatar/

[21] Raudeliūniené, J., et al. (2020). Knowledge Management Practice in General Education Schools as a Tool for Sustainable Development. MDPI. https://www.mdpi.com/2071-1050/12/10/4034\#cite

[22] Richer, R. (2009, January). Conservation in Qatar: Impacts of Increasing Industrialization. Research Gate. https://www.researchgate.net/publication/254158379_Conservation_in_Qatar_Impacts_of_Increasing_Industrialization

[23] Sowers, J., Vengosh, A., \& Weinthal, E. (2010, April 23). Climate change, water resources, and the politics of adaptation in the Middle East and North Africa. SpringerLink. https://link.springer.com/article/10.1007/s10584-010-9835-4

[24] Sutherland, M. R. (2018, May 8). Conservation education in schools: Aligning teachers' perceptions with students' attitudes. NAAEE. https://naaee.org/eepro/research/library/conservation-education-schools-aligning

[25] Tara Energy. (2021, May 14). Your guide to understanding energy conservation. https://taraenergy.com/blog/your-guide-to-understanding-energyconservation/

[26] Xevgenos, D., Moustakas, K., Malamis, D., \& Loizidou, M. (2014, December 1). An overview on desalination \& sustainability: renewable energydriven desalination and brine management. Desalination and Water Treatment. https://www.tandfonline.com/doi/abs/10.1080/19443994.2014.984927

[27] Zafar, S. (2021, August 8). Waste management in Qatar. BioEnergy Consult. https://www.bioenergyconsult.com/waste-management-qatar/

\section{Appendix A.}

\section{A.1. Biographical Sketch}

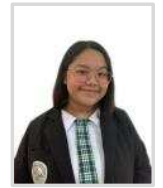

Anne Beatrice A. Jose is from Taguig City, Metro Manila. She was born on March 25, 2005. She has been part of the top section in her grades 1 to 7 and 10. She is a consistent Bronze awardee since grade 1. She is currently a grade 11 STEM student and is the Vice President of the Supreme Student Government. She lives by the quote "Without the rain, we would never feel thankful for the warmth of the sun."

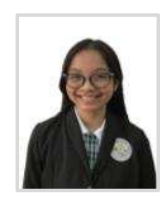

Roma Angelica N. Manaois is from Mangatarem, Pangasinan. She was born on November 20, 2004. She has been part of the top section of Philippine School Doha for 9 consecutive years. She is currently a grade 11 student and is the managing editor of the school paper known as The Link. She is also the class treasurer of her section. She believes in the quote "What you seek is seeking you."

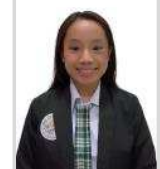

Ma. Angela Jayne M. Mandin is from South Cotabato, Cotabato City. She was born on January 25, 2005. She has been a student from the top section of Philippine School Doha for 7 consecutive years. She was a silver awardee for SY 2019-2020. She participated in the school's Sipnayan SY 2019-2020, winning 2nd runner-up. She is currently the class secretary of her section. She swears by the quote of Napolean Hill, "If you cannot do great things, do small things in a great way." 